\title{
Informatization in Ukraine: Realities, Problems, Prospects
}

\author{
By Mariia Danyliuk ${ }^{1}$, Marta Dmytryshyn ${ }^{2}$, Tetyana Goran ${ }^{3}$
}

\begin{abstract}
Modern sustainable development depends on innovative technologies, complete and adequate information at the right time and place. Ukraine did not stay apart from the world plan to reach sustainable goals until 2030. The global coronavirus pandemic has made adjustments in the development of societies and nations as work, study, and even social contacts have gone online. In this matter, informatization will be on the agenda around the world until it entirely and irreversibly changes it. Due to this, the paper examines the current realities of informatization in Ukraine regarding the pace of information and communication services dissemination, coverage of households with Internet access, and salaries in the industry. Regional measurement of information and communication services is presented. The place of Ukraine in the rating of the Network Readiness Index in 2019-2020 also is analyzed, the strengths and weaknesses of our state in modern informatization are revealed. Based on the conducted research, the distribution of information and communication services in Ukrainian regions and the state as a whole are forecasted; the factors of direct and indirect influence of informatization on the society, economy, and the state are formulated.
\end{abstract}

Keywords: sustainability, information and communication services, informatization, Internet access, Network. Readiness Index, Ukraine

\section{Introduction}

From the moment of transition from the industrial to the information society, information occupies a prominent place in many relationships, operations, and decisions. Information becomes a commodity; it is distributed, processed, transformed, and even stolen. After all, a timely informed subject has a much greater chance of success than one who lacks information, whether it is false or incomplete.

Informatization is a set of interconnected organizational, legal, political, socio-economic, scientific and technical, production processes aimed at creating conditions to meet information needs, the realization of the rights of citizens and society through the creation, development, use of information systems, networks, resources, and information technology, created based on modern computer and communication technology (National Commission for the State Regulation of Communications and Informatization), has long been a critical vector for the progress of both developed and developing countries. For instance, online services can help involve the public in local development decisions (Danyliuk, M. \& Dmytryshyn, M. 2021) or e-government in general (Defitri, S. Y. et al., 2020)

\footnotetext{
| ${ }^{1} \mathrm{PhD}$ in Economic Sciences, Associate Professor in the Department of Management and Administration, Ivano-Frankivsk Educational and Scientific Institute of Management, West Ukrainian National University, 76015 Ivano-Frankivsk, Ukraine

${ }^{2} \mathrm{PhD}$ in Economic Sciences, Associate Professor in the Department of Management and Administration, Ivano-Frankivsk Educational and Scientific Institute of Management, West Ukrainian National University, 76015 Ivano-Frankivsk, Ukraine; Corresponding Author

${ }^{3} \mathrm{PhD}$ in Historical Sciences, Senior Lecturer in the Department of International economics, Marketing and Management, Ivano-Frankivsk Educational and Scientific Institute of Management, West Ukrainian National University, 76015 Ivano-Frankivsk, Ukraine
} 
However, the informatization of society poses difficulties and threats. This includes the high cost of computers and computer equipment, systems, and networks, the need for training and protection of confidential data. In addition, new opportunities have created the need to digitize information, which facilitates its processing and storage. Nevertheless, at the same time, this led to the threat of job losses in those areas where technology has begun to replace people with higher efficiency.

Thus, today the industry has a task to improve the quality of life in general, without deteriorating the living conditions of some people; create new opportunities and prospects; to unite people from all over the world on the World Wide Web to achieve the goals of sustainable development (Sustainable development goals).

Our state has not stayed apart from modern changes. In 2019, a special Ministry of Digital Transformation of Ukraine was created, which sets ambitious goals to be achieved by 2024 (Goals to 2024):

- $100 \%$ availability of public services for citizens and businesses online.

- High-speed Internet coverage of $95 \%$ of the population, social facilities, and highways.

- Involvement of 6 million Ukrainians in the digital skills development program.

- Achieving a 10\% share of the IT sector in the gross domestic product of the state.

The global coronavirus pandemic has made its adjustments in the development of societies and nations as work, study, and even social contacts have gone online.

In this matter, informatization will be on the agenda around the world until it entirely and irreversibly changes it.

\section{Literature Review}

The information has been discussed in many scientific papers by researchers all over the world. In particular, Yao et al. (2020) have evaluated the informatization performance of construction industrialization EPC enterprises in China; Zhu, J., \& Sun, Y. (2020) have made the dynamic modeling and chaos control of sustainable integration of informatization and industrialization; Mwalupaso G. E. et al. (2020) have searched for the answer if information matters for ameliorating Food and Nutrition Security in Farm Households; Gebre-Mariam, M., \& Bygstad, B. (2019) have established the digitalization mechanisms of health management information systems in developing countries; Cherniavskyi, S. et al. (2021) have been searching for the peculiarities of the committed using information technologies economic crimes; Hamdi, H. O. T. I., \& Kurhasku, E. (2021) have studied the impact of information technology on the HR practices in the public sector; Shevchuk, O. et al. (2021) have investigated human rights to Internet access. Questions about it were put and answered in conferences; for instance, Drotianko L. et al. (2020) have investigated the functional aspect in the post-non-classical science in the age of informatization of society; Ordenov S. et al. (2020) have clarified the problems in modern society in the processes of informatization and globalization; Zadorozhnyi, Z. M., \& Muravskyi, V. (2020) have performed an analysis of the implementation efficiency of the new computer-communication form of accounting; Melnyk, N. et al. (2020) have modeled the seller behavior in the Ukrainian computer market.

Digital changes and informatization was a popular topic of scientific researches in Malaysia. For example, Ghapa N. \& Kadir N. (2021) have counted a measure of consumer 
protection in the context of information regulations; Daud M. \& Azmi G. (2021) have been investigating the problem of digital disinformation; Abdullah N. et al. (2021) have substantiated the intellectual property challenges in Malaysia due to the digital era.

Finally, informatization becomes on the agenda of education. In this context, Long, H. et al. (2020) have made a research on the development of project cost informatization in the era of big data; Zhang, H., \& Fang, M. (2020) - on the integration of heterogeneous information resources in university management informatization based on data mining algorithms; Lytvyn, A. et al. (2020) - theoretical foundations and practical approaches of informatization of technical vocational schools.

\section{Materials and Methods}

\subsection{Informational and Communication Services' Analysis}

The study of informatization in Ukraine should begin with data analysis on the country's spread of information and communication services (Table 1-2).

With the rapidly changing realities of daily life, the way statistics are provided by the official statistics service is also changing, as many IT companies are no longer tied to the region. In addition, the dynamics of information and communication services also depend on the stages of sowing and harvesting, the peak of industrial production and energy load, training, and vacations, etc.; consequently, for the analysis, we will use quarterly data for the last 2 years.

Table 1. Regional measurement of information and communication services in Ukraine over the quarters of 2019-2020, UAH thousand

\begin{tabular}{|c|c|c|}
\hline Region & IQ 2019 - IVQ 2020 & Difference \\
\hline Vinnytsia & $707.8 \mathrm{~K}$ & 248,190 \\
\hline Volyn & $104.4 \mathrm{~K}$ & 3,506 \\
\hline Dnipropetrovsk & $908.9 \mathrm{~K} \bullet$ & 137,532 \\
\hline Donetsk & $742.3 \mathrm{~K}-$ & $-129,717$ \\
\hline Zhytomyr & $180.7 \mathrm{~K}$ & 40,135 \\
\hline Zakatpattya & • $100.5 \mathrm{~K}$ & 8,524 \\
\hline Zaporizhzhya & $328.4 \mathrm{~K}$ & $-67,327$ \\
\hline Ivano-Frankivsk & $129.2 \mathrm{~K} \bullet$ & 24,673 \\
\hline Kyiv & $321 \mathrm{~K}$ & 130,241 \\
\hline Kirovohrad & $73.6 \mathrm{~K}$ & $-8,762$ \\
\hline Luhansk & $43.4 \mathrm{~K} \bullet$ & $-8,103$ \\
\hline Lviv & $2.3 \mathrm{M}$ & 380,393 \\
\hline Mykolayiv & - $206.5 \mathrm{~K}$ & 42,329 \\
\hline Odesa & $684 \mathrm{~K} \propto$ & $-96,635$ \\
\hline Poltava & $220 \mathrm{~K}$ & 8,807 \\
\hline Rivne & $65.9 \mathrm{~K}$ & 4,688 \\
\hline Sumy & $107.2 \mathrm{~K} \propto$ & 13,874 \\
\hline Ternopil & $129.6 \mathrm{~K} \bullet$ & 29,848 \\
\hline Kharkiv & • $2.5 \mathrm{M}$ & 418,057 \\
\hline Kherson & $86.6 \mathrm{~K} \curvearrowleft$ & 7,821 \\
\hline Khmelnytskyi & $89.4 \mathrm{~K} \propto$ & 8,228 \\
\hline Cherkasy & $260.1 \mathrm{~K}$ & 39,178 \\
\hline Chernivtsi & $126.9 \mathrm{~K}$ & 9,354 \\
\hline Chernihiv & $\longrightarrow 160.3 \mathrm{~K}$ & 10,588 \\
\hline
\end{tabular}

Source: Constructed based on Volume of services sold by service rendering enterprises to different users by type of economic activity I quarter 2019 - IV 2020 by the tools of Datawrapper 
It should be noted that the overall indicator given in the statistics includes the following subcomponents:

- Publishing activities.

- Motion picture, video, and television program production, sound recording, and music publishing activities.

- Programming and broadcasting activities.

- Telecommunications (electric communications).

- Computer programming, consultancy, and related activities.

- Information service activities.

Table 1. Total regional and capital mensuration of information and communication services in Ukraine over the quarters of 2019-2020, UAH thousand

\begin{tabular}{|c|c|c|}
\hline Region & IQ 2019 - IVQ 2020 & Difference \\
\hline Kyiv city & $16.8 \mathrm{M} \bullet$ & $5,681,012$ \\
\hline Total & $41.5 \mathrm{M} \bullet$ & $12,228,220$ \\
\hline
\end{tabular}

Source: Constructed based on Volume of services sold by service rendering enterprises to different users by type of economic activity I quarter 2019 - IV quarter 2020 by the tools of Datawrapper

From Tables 1 and 2, it is noticeable that the provision of information and communication services increased in the country as a whole, but some regions showed a decrease (Donetsk, Zaporizhzhia, Kirovohrad, Luhansk, Odesa regions). The sharpest decline occurred in the Donetsk region, the most industrialized region, which is, however, close to active hostilities.

Information and communications are actively disseminated in the capital of Ukraine Kyiv, as well as Vinnytsia, Dnipropetrovsk, Kyiv, Lviv, and Kharkiv regions. If Dnipro and Kharkiv are powerful industrial centers, Lviv and Vinnytsia confidently secure the role of macro-regional leaders.

If we depict the volume of provided information and communication services on the territory of Ukraine in 2020 (Fig. 1), we will see significant heterogeneity and their accumulation in some regions.

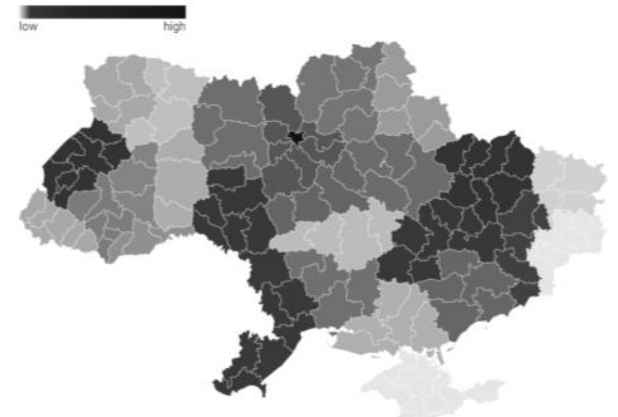

Figure 1. The regional capacity of information and communications services in Ukraine in 2020, UAH thousand Source: Constructed based on Volume of services sold by service rendering enterprises to different users by type of economic activity I quarter 2019 - IV quarter 2020 by the tools of Datawrapper 
This can eventually lead to increased differentiation in people's living standards in the "light" zones of lower development.

\subsection{Internet users' analysis}

The basis of information dissemination is the connection of its users to the World Wide Web. People can work and study on the Internet, watch shows, read books, buy and sell goods, negotiate business, and establish contacts.

Due to the statistics data, approximately 4.93 billion people have Internet access and use it frequently. Therefore, about $63.2 \%$ of the total world population is 7.8 billion (2021 General Internet Usage Statistics).

Next, we will consider the dynamics of Internet users among households in Ukraine (Table 3)

Table 3. Share of households with internet access in 2015-2019, \%

\begin{tabular}{|c|c|c|}
\hline $\begin{array}{l}\text { Share of households } \\
\text { with Internet access }\end{array}$ & $2015-2019$ & Difference \\
\hline Urban area & $\longrightarrow 76.3$ & 14.2 \\
\hline Rural area & $\longrightarrow 44.1$ & 16.9 \\
\hline Total & $\longrightarrow 65.8$ & 15.1 \\
\hline
\end{tabular}

Source: Constructed based on Statistical Yearbook of Ukraine 2017 and Statistical Yearbook of Ukraine 2019 by the tools of Datawrapper

The problem of inequality of Internet coverage of urban and rural areas is a Ukrainian problem and characteristic of many other countries. The rural area is usually less populated; namely, there is a much lower density of people and businesses. In addition, part of Ukraine consists of mountainous areas, which complicates effective communication in hard-to-reach places. For Ukraine, as a low-middle-income country, this can be costly.

In fig. 2 shows the structural ratio of Internet users in terms of regions of Ukraine.

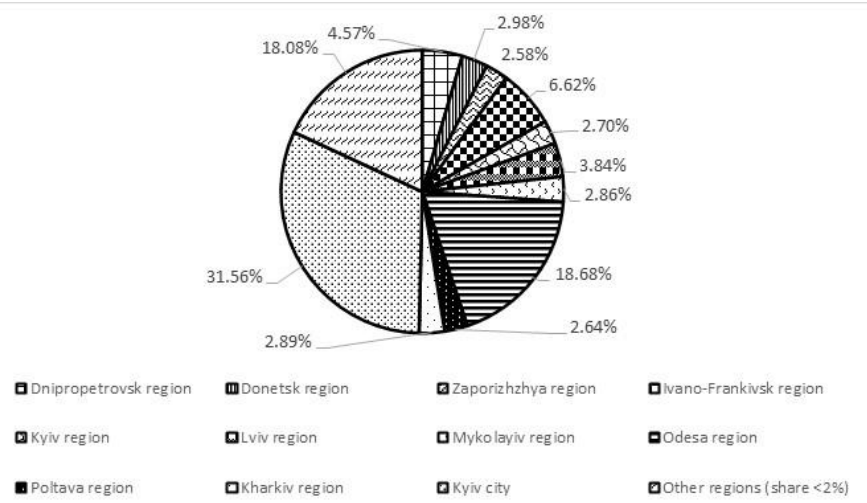

Figure 2. Regional share of households with Internet access in 2019, \%

Source: Constructed based on Statistical Yearbook of Ukraine 2019 
According to Figure 2, the largest share of households using the Internet lives in Kyiv city and the region, which has access to the sea. However, referring to the data in Table 1, we can assume that the share of the Odesa will decline next year. A very promising indicator in the tourist mountain west Ivano-Frankivsk region. In addition, 15 regions have a share of household Internet coverage of less than $2 \%$ of the national average. This, in turn, further indicates a concentration in large cities.

\subsection{Network Readiness Index' analysis}

In October 2020, Portulas institute had done annual research on accelerating digital transformation in a post-COVID global economy and counted The Network Readiness Index 2020 (Network Readiness Index 2020). As a result, Ukraine was ranked 64 among 134 economies worldwide average rank in general, but the second in a group of lower-middle-income countries.

Network Readiness Index was formed with 4 pillars, including 3 sub-pillar each. As a result, our country index has a difference in rank and scores this year (Table 4).

Table 4. Ukraine in network readiness index 2020

\begin{tabular}{|l|c|c|c|c|c|c|}
\hline \multirow{2}{*}{ Pillars } & \multicolumn{3}{|c|}{ Rank } & \multicolumn{3}{c|}{ Score } \\
\cline { 2 - 7 } & $\mathbf{2 0 1 9}$ & $\mathbf{2 0 2 0}$ & $\mathbf{\Delta}$ & $\mathbf{2 0 1 9}$ & $\mathbf{2 0 2 0}$ & $\boldsymbol{\Delta}$ \\
\hline A. Technology & $\mathbf{7 1}$ & $\mathbf{6 2}$ & $\uparrow \mathbf{9}$ & $\mathbf{4 3 , 0 1}$ & $\mathbf{4 1 , 5 1}$ & $\mathbf{- 1 , 5 0}$ \\
\hline Access & 78 & 79 & $\downarrow \mathbf{1}$ & 53,72 & 54,12 & $\mathbf{+ 0 , 4 0}$ \\
\hline Content & 56 & 46 & $\uparrow \mathbf{1 0}$ & 48,74 & 39,9 & $\mathbf{- 8 , 8 4}$ \\
\hline Future Technologies & 82 & 53 & $\uparrow \mathbf{2 9}$ & 26,57 & 30,55 & $+\mathbf{3 , 9 8}$ \\
\hline B. People & $\mathbf{6 3}$ & $\mathbf{6 5}$ & $\downarrow \mathbf{2}$ & $\mathbf{4 2 , 0 5}$ & $\mathbf{4 8 , 8 7}$ & $\mathbf{+ 6 , 8 2}$ \\
\hline Individuals & 68 & 63 & $\uparrow \mathbf{5}$ & 53,88 & 56,22 & $\mathbf{+ 2 , 3 4}$ \\
\hline Businesses & 48 & 52 & $\downarrow 4$ & 35,69 & 48,53 & $\mathbf{+ 1 2 , 8 4}$ \\
\hline Governments & 87 & 71 & $\uparrow 16$ & 36,58 & 41,85 & $\mathbf{+ 5 , 2 7}$ \\
\hline C. Governance & $\mathbf{6 7}$ & $\mathbf{5 8}$ & $\uparrow \mathbf{9}$ & $\mathbf{5 8 , 3 2}$ & $\mathbf{5 8 , 1 9}$ & $\mathbf{- 0 , 1 3}$ \\
\hline Trust & 70 & 49 & $\uparrow \mathbf{2 1}$ & 53,00 & 50,66 & $\mathbf{- 2 , 3 4}$ \\
\hline Regulation & 72 & 83 & $\downarrow \mathbf{1 1}$ & 61,26 & 61,48 & $\mathbf{+ 0 , 2 2}$ \\
\hline Inclusion & 70 & 72 & $\downarrow \mathbf{2}$ & 60,69 & 62,42 & $\mathbf{+ 1 , 7 3}$ \\
\hline D. Impact & $\mathbf{6 5}$ & $\mathbf{7 9}$ & $\downarrow \mathbf{1 4}$ & $\mathbf{5 2 , 3 1}$ & $\mathbf{4 9 , 1 6}$ & $\mathbf{- 3 , 1 5}$ \\
\hline Economy & 75 & 62 & $\uparrow \mathbf{1 3}$ & 15,76 & 26,17 & $\mathbf{+ 1 0 , 4 1}$ \\
\hline Quality of Life & 82 & 77 & $\downarrow \mathbf{5}$ & 54,97 & 62,86 & $\mathbf{+ 7 , 8 9}$ \\
\hline SDG Contribution & 43 & 91 & $\downarrow \mathbf{4 8}$ & 86,22 & 58,46 & $\mathbf{- 2 7 , 7 6}$ \\
\hline Network Readiness Index & $\mathbf{6 7}$ & $\mathbf{6 4}$ & $\uparrow \mathbf{3}$ & $\mathbf{4 8 , 9 1}$ & $\mathbf{4 9 , 4 3}$ & $\mathbf{+ 0 , 5 2}$ \\
\hline
\end{tabular}

Source: Constructed based on Network Readiness Index 2020 and Network Readiness Index 2019

We have made progress in Technology and Governance pillars but fell in People and Impact pillars. We still have to do much in $4 \mathrm{G}$ mobile network coverage, handset prices, active mobile-broadband subscriptions, affordable and clean energy, and quality of life (ranks lower than 100).

Need to be noted that some indicators added in the score but got a lower rank than it was in 2019. Generally, it means that we have developed a specific feature, but still not fast enough. 


\subsection{Information and communication services trend' analysis}

In order to assess the prospects of Ukraine's development in the information sphere, we have built a trend of regional mensuration of information and communication services in the country in 2021 (Table 5).

Table 5. 2021 trend of regional mensuration of information and communication services in Ukraine

\begin{tabular}{|c|c|c|}
\hline Regions & $\begin{array}{l}\text { Polynomial trends, } \\
\text { coefficients of determination }\end{array}$ & \begin{tabular}{|l|l|l} 
\\
\end{tabular} \\
\hline Total (regions) & $\begin{array}{c}y=-9360 x^{6}+238631 x^{5}-2 E+06 x^{4}+1 E+07 x^{3}-2 E+07 x^{2}+3 E+07 x \\
+2 E+07, R^{2}=0.9997\end{array}$ & 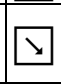 \\
\hline Vinnytsia & $\begin{array}{c}y=397.34 x^{6}-9675.7 x^{5}+92334 x^{4}-440232 x^{3}+1 E+06 x^{2}-1 E+06 x+ \\
1 E+06, R^{2}=0.9087\end{array}$ & $\nearrow$ \\
\hline Volyn & $\begin{array}{c}y=30.394 x^{6}-869.08 x^{5}+9876.8 x^{4}-56363 x^{3}+167222 x^{2}-238037 x+ \\
219186, R^{2}=0.5135\end{array}$ & 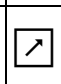 \\
\hline Dnipropetrovsk & $\begin{array}{c}y=-389.23 x^{6}+9695.8 x^{5}-91665 x^{4}+413983 x^{3}-929271 x^{2}+976443 x \\
+529901, R^{2}=0.9973\end{array}$ & $\nabla$ \\
\hline Donetsk & $\begin{array}{c}y=426.22 x^{6}-12831 x^{5}+153150 x^{4}-912145 x^{3}+3 E+06 x^{2}-4 E+06 x+ \\
3 E+06, R^{2}=0.9824\end{array}$ & 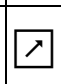 \\
\hline Zhytomyr & $\begin{array}{c}y=-47.117 x^{6}+1387 x^{5}-15712 x^{4}+85885 x^{3}-231180 x^{2}+280243 x+ \\
60147, R^{2}=0.9994\end{array}$ & $\nearrow$ \\
\hline Zakatpattya & $\begin{array}{c}y=7.1628 x^{6}-136.71 x^{5}+785.42 x^{4}-550.38 x^{3}-6817.7 x^{2}+15002 x+ \\
83580, R^{2}=0.9163\end{array}$ & $r$ \\
\hline Zaporizhzhya & $\begin{array}{c}y=72.9 x^{6}-1974.7 x^{5}+21330 x^{4}-117990 x^{3}+357517 x^{2}-578085 x+ \\
647306, R^{2}=0.9583\end{array}$ & $\nearrow$ \\
\hline Ivano-Frankivsk & $\begin{array}{c}y=-108.41 x^{6}+2905.5 x^{5}-30252 x^{4}+154325 x^{3}-400018 x^{2}+494320 x \\
-92077, R^{2}=0.8761\end{array}$ & $\nabla$ \\
\hline Kyiv & $\begin{array}{c}y=-278.87 x^{6}+6272.3 x^{5}-50640 x^{4}+172232 x^{3}-200214 x^{2}-46034 x+ \\
441518, R^{2}=0.6393\end{array}$ & $\Delta$ \\
\hline Kirovohrad & $\begin{array}{c}y=-220.24 x^{6}+6013.9 x^{5}-64122 x^{4}+337545 x^{3}-912244 x^{2}+1 E+06 x \\
-461419, R^{2}=0.999\end{array}$ & $\nabla$ \\
\hline Luhansk & $\begin{array}{c}y=38.342 x^{6}-1010.7 x^{5}+10268 x^{4}-50333 x^{3}+122111 x^{2}-137565 x+ \\
99871, R^{2}=0.932\end{array}$ & $\lambda$ \\
\hline Lviv & $\begin{array}{c}y=-162.52 x^{6}+4467.5 x^{5}-43586 x^{4}+177684 x^{3}-235871 x^{2}-121435 x \\
+2 E+06, R^{2}=0.9817\end{array}$ & $\triangle$ \\
\hline Mykolayiv & $\begin{array}{c}y=-77.041 x^{6}+1780.1 x^{5}-14877 x^{4}+53261 x^{3}-69951 x^{2}+3201.5 x+ \\
191124, R^{2}=0.8998\end{array}$ & $\nabla$ \\
\hline Odesa & $\begin{array}{c}y=-357.24 x^{6}+9556.3 x^{5}-100063 x^{4}+517880 x^{3}-1 E+06 x^{2}+2 E+06 x \\
-42464, R^{2}=0.9884\end{array}$ & $\searrow$ \\
\hline Poltava & $\begin{array}{c}y=-65.533 x^{6}+1569.4 x^{5}-13707 x^{4}+51913 x^{3}-73252 x^{2}-2602.4 x+ \\
256183, R^{2}=0.9752\end{array}$ & 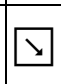 \\
\hline Rivne & $\begin{array}{c}y=55.307 x^{6}-1516.9 x^{5}+16386 x^{4}-87850 x^{3}+240856 x^{2}-310432 x+ \\
208255, R^{2}=0.7609\end{array}$ & 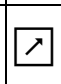 \\
\hline Sumy & $\begin{array}{c}y=6.8525 x^{6}-206.13 x^{5}+2442.9 x^{4}-14524 x^{3}+46500 x^{2}-77104 x+ \\
149954, R^{2}=0.9571\end{array}$ & $\nearrow$ \\
\hline Ternopil & $\begin{array}{c}y=55.095 x^{6}-2017.7 x^{5}+27921 x^{4}-184551 x^{3}+599495 x^{2}-871097 x+ \\
559903, R^{2}=0.9828\end{array}$ & 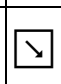 \\
\hline
\end{tabular}




\begin{tabular}{|c|c|c|}
\hline Regions & $\begin{array}{l}\text { Polynomial trends, } \\
\text { coefficients of determination }\end{array}$ & 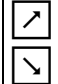 \\
\hline Kharkiv & $\begin{array}{c}y=986.47 x^{6}-29067 x^{5}+335008 x^{4}-2 E+06 x^{3}+5 E+06 x^{2}-7 E+06 x+ \\
5 E+06, R^{2}=0.9229\end{array}$ & $\nabla$ \\
\hline Kherson & $\begin{array}{c}y=-45.661 x^{6}+1176.5 x^{5}-11669 x^{4}+55959 x^{3}-133557 x^{2}+146937 x \\
+27844, R^{2}=0.9997\end{array}$ & $\Delta$ \\
\hline Khmelnytskyi & $\begin{array}{c}y=-39.957 x^{6}+972.3 x^{5}-8977.6 x^{4}+39240 x^{3}-82308 x^{2}+74323 x+ \\
66202, R^{2}=0.9834\end{array}$ & $\nabla$ \\
\hline Cherkasy & $\begin{array}{c}y=162.61 x^{6}-4333.1 x^{5}+45547 x^{4}-239209 x^{3}+653365 x^{2}-864210 x+ \\
668826, R^{2}=0.9961\end{array}$ & $\nearrow$ \\
\hline Chernivtsi & $\begin{array}{c}y=-5.7319 x^{6}+376.14 x^{5}-7641.4 x^{4}+71504 x^{3}-338048 x^{2}+772873 x \\
-545652, R^{2}=1\end{array}$ & 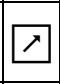 \\
\hline Chernihiv & $\begin{array}{c}y=20.543 x^{6}-687.9 x^{5}+8980.3 x^{4}-57845 x^{3}+190893 x^{2}-296613 x+ \\
305081, R^{2}=0.8738\end{array}$ & $\nabla$ \\
\hline Kyiv city & $\begin{array}{c}y=-9942.2 x^{6}+260428 x^{5}-3 E+06 x^{4}+1 E+07 x^{3}-3 E+07 x^{2}+ \\
4 E+07 x+244886, R^{2}=0.9992\end{array}$ & $\nabla$ \\
\hline
\end{tabular}

Source: Constructed based on Volume of services sold by service rendering enterprises to different users by type of economic activity I quarter 2019 - IV quarter 2020 and calculated in Microsoft Excel

In the regional context, it showed the prospects for both growth and decline. Dnipropetrovsk Ivano-Frankivsk Kyiv Kirovohrad Mykolayiv Odesa Poltava Ternopil Kharkiv Kherson Khmelnytskyi Chernihiv regions and Kyiv city risk to reduce the total amount of information and communication services, as well as the country as a whole. However, to keep up with the modern moving world, everything around must move faster.

\subsection{Average salary' analysis}

To find out the possible prospect in information and communication services growth, we have analyzed an average salary in the country as a whole and this particular sphere, for instance (Table 6).

Table 6. The average salary in Ukraine in 2019-2020, EUR

\begin{tabular}{lll} 
Average salary & January, 2019 - December, 2020 & Difference \\
\hline Country & $\longrightarrow 408.2$ & 117 \\
\hline $\begin{array}{l}\text { Information and } \\
\text { communication }\end{array}$ & & \\
\hline
\end{tabular}

Source: Constructed based on Average salary January 2019 - December 2020 (monthly) and Official Exchange Rates by the tools of Datawrapper

As shown in Table 6, the average salary in informatization and communications is $60-70 \%$ higher than the average in Ukraine. This can contribute to the influx of staff and activity in the future. However, average salaries in Ukraine still remain close to the minimum in Europe, making working abroad attractive for many qualified Ukrainians (Fig. 3). 


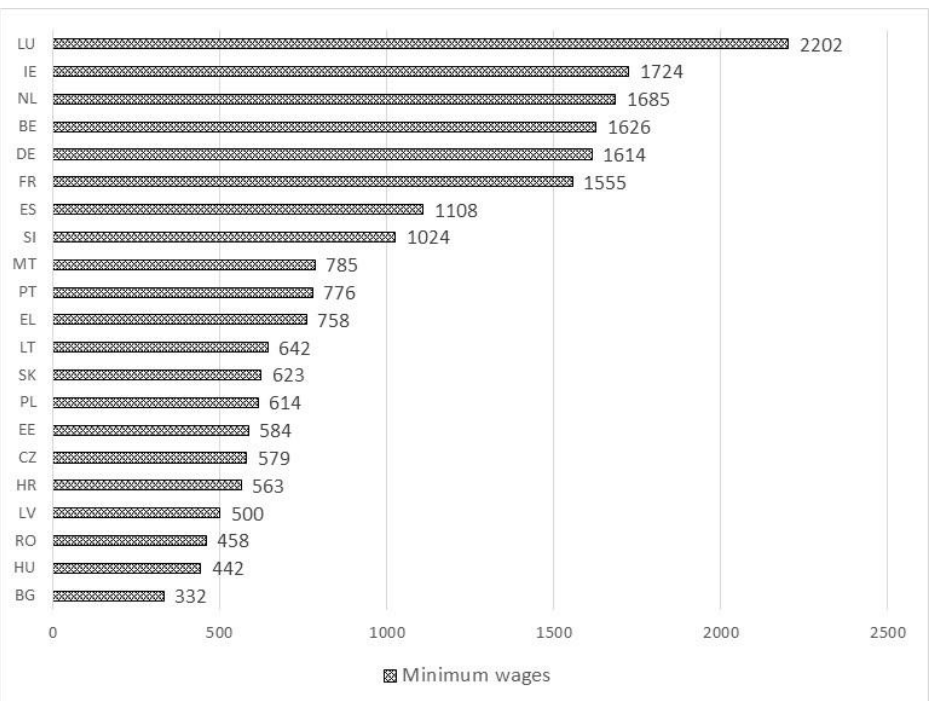

Figure 3. Minimum wages in European Union (January 2021), EUR (Disparities in minimum wages across the $E U)^{1}$

\section{Results and discussion}

It should be noted that informatization and digitalization are worldwide trends in recent years. The potential and prospects of its progress depend on the country's level of information technology development; otherwise, the informatization has a direct and indirect impact on the state as a whole and specific areas of its economy, in particular (Fig. 4).

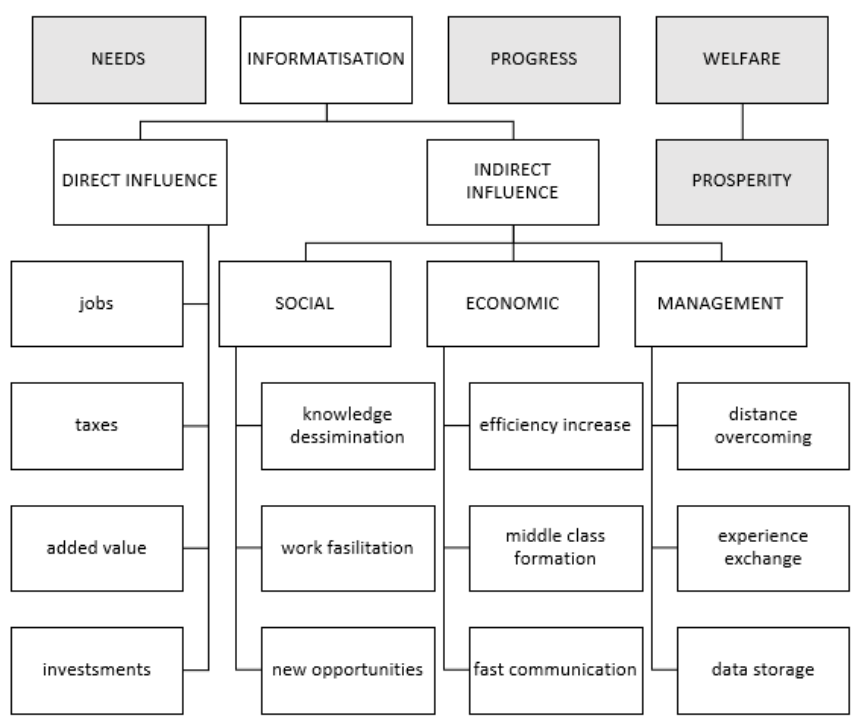

Figure 4. Informatization direct and indirect impact

121 out of 27 EU Member States have a national minimum wage 
The direct consequence of informatization, in our opinion, is:

- The development of book publishing, cinematography, programming, and general digitalization in all spheres of life increases the demand for information services and, consequently, gives an incentive to increase the popularity of vocational education in the field of information and the emergence of new enterprises. Furthermore, this, in turn, creates additional jobs, increases the employment of a highly qualified population by paying people a decent salary due to the standards of Ukraine.

- Accordingly, the operation of new business entities leads to an increase in tax payments of both general nature (business income tax) and payroll tax (personal income tax). Thus, the State Budget of Ukraine and the budget of the Pension Fund of Ukraine are filled, as well as the treasuries of the communities where such economic entities are located.

- Enterprises in the information sphere create additional value, scilicet participate in the production of gross domestic product, which is the basis of the progress of any state. In addition, innovative products are created that are patented, protected by copyright, and later distributed through communication systems.

- The industry's attractiveness generally causes an influx of investment in the country and, thus, contributes to increasing its investment attractiveness, obtaining foreign currency inflow, stabilizing the political and legal system, and increasing the economy and society's innovation aggregate.

In addition to the factors mentioned above of direct influence, informatization also indirectly affects the state. Therefore, we divided these factors into three subcomponents: social, economic, and managerial.

As part of the indirect impact on the social sphere, informatization:

- Disseminates information creates opportunities for learning, training, and acquiring a new profession even remotely.

- Facilitates work in various areas of the economy, other than information and communication. New mechanisms and devices, programs and networks, methods of processing and storing information transfer complex and often routine work to the computer.

- Creates new opportunities for personal development: training, work, replenishment of intellectual capital of the people, testing new ideas, and finding investors for innovative developments.

The economic subcomponent of the impact of informatization on the lives of people and the state includes:

- Improving the economy's overall efficiency: reducing energy consumption, increasing the quality of products and services, creating and distributing daily work or the life of machines and devices.

- Formation of a middle class of well-educated professionals who have sufficient means of subsistence and appropriate qualifications for self-development. Such people can already mentally move from the values of survival to the values of self-realization; they are often indifferent to the fate of the country and the people, ready to take an active part in public life and politics.

- Acceleration of communications, which is reflected in the speed of transfer and dissemination of knowledge or information, and ease of interstate communication 
(simultaneous translation, video conferencing with representatives of different continents, cloud technologies, data presentation, etc.).

Finally, information and communication technologies allow to develop the management systems, create mechanisms for implementing decision-making systems in various fields:

- Today, distances do not matter not only in private communications but also in work. Programs and networks allow working in multinational companies without even leaving home.

- This allows, in turn, to actively share the progressive and successful management experience, to disseminate it from the holding company to subsidiaries (while developing the region of the branch).

- The global data storage system no longer requires the study of fragile volumes in libraries, and the mass of information needed for effective management is available online. This allows making effective decisions by processing arrays of reports, surveys, previous successes, and failures.

\section{Conclusions}

Thus, our study allowed us to assess the current state in general, identify existing problems and outline prospects for the development of modern information and communication technologies, and formulate the following conclusions:

Information and communication services on the territory of our state are provided unevenly, concentrated more in industrialized regions and large cities.

Future trends in the spread of information and communication services have divergent trends that do not provide growth against the background of quarantine restrictions.

Two-thirds of Ukrainian households are connected to the Internet, and the share of Internet users is growing.

Coverage of access to the World Wide Web in villages is much lower than in cities.

The level of wages in informatization and communications is much higher than the average level in the country as a whole; however, it remains uncompetitive compared to the level of wages in developed market countries.

Ukraine has risen by 3 positions in the Network Readiness Index, which indicates some changes in the informatization and digitalization of our country, but the pace of such changes is still insufficient.

Summarizing the above, we believe that Ukraine is in the trend of global tendencies towards mass informatization of the economy and society, as among the leaders of the group of countries with incomes below average. However, the world is evolving rapidly, leaving no room for error, delay, or reflection. Therefore, there is a crucial need to understand these trends, use their benefits, and act ahead.

\section{References}

2021 General Internet Usage Statistics. https://www.broadbandsearch.net/blog/internet-statistics\#postnavigation- 0

Abdullah N., Hanafi H. \& Navang N. (2021). Digital Era and Intellectual Property Challenges in Malaysia. Pertanika Journal of Social Science and Humanities, Vol. 29(S2), 205-219. 
Average salary January 2019 - December 2020 (monthly). http://www.ukrstat.gov.ua

Cherniavskyi, S., Babanina, V., Vartyletska, I., \& Mykytchyk, O. (2021). Peculiarities of The Economic Crimes Committed with the Use of Information Technologies. European Journal of Sustainable Development, 10(1), 420-420. https://doi.org/10.14207/ejsd.2021.v10n1p420

Danyliuk M. \& Dmytryshyn M. (2021). Adopted municipal real estate property in Ukraine: problems and prospects. Public policy and administration, 20(2), 164-175. https://doi.org/10.13165/VPA-21-20-2-02 Datawrapper. https://www.datawrapper.de/

Daud M. \& Azmi G. (2021). Digital Disinformation and the Need for Internet Co-regulation in Malaysia. Pertanika Journal of Social Science and Humanities, Vol. 29(S2), 169-183. https://doi.org/10.47836/pjssh.29.s2.12

Defitri, S. Y., Bahari, A., Handra, H., \& Febrianto, R. (2020). Determinant factors of e-government implementation and public accountability: toe framework approach. Public Policy and Administration, 19(4), 37-51. https://doi.org/10.13165/VPA-20-19-4-03

Disparities in minimum wages across the EU. https://ec.europa.eu/eurostat/en/web/products-eurostatnews/-/ddn-20210205-1

Drotianko, L., Abysova, M., Chenbai, N., \& Shorina, T. (2020). Post-non-classical science in the age of informatization of society: functional aspect. In E3S Web of Conferences (Vol. 157, p. 04003). EDP Sciences. https://doi.org/10.1051/e3sconf/202015704003

Gebre-Mariam, M., \& Bygstad, B. (2019). Digitalization mechanisms of health management information systems in developing countries. Information and Organization, 29(1), 1-22. https://doi.org/10.1016/i.infoandorg.2018.12.002

Ghapa N. \& Kadir N. (2021). Information Regulation: A Measure of Consumer Protection. Pertanika Journal of Social Science and Humanities, Vol. 29(S2), 59-74. https://doi.org/10.47836/pjssh.29.s2.05

Goals to 2024 (Ministry of Digital Transformation of Ukraine). https://thedigital.gov.ua/ministry

Hamdi, H. O. T. I., \& Kurhasku, E. (2021). Impact of Information Technology on the HR Practices in the Public Sector: Evidence from the Republic of Kosovo. European Journal of Sustainable Development, 10(1), 724-724. https://doi.org/10.14207/ejsd.2021.v10n1p724

Long, H., Ma, Y., Mao, X., \& Sun, X. (2020). Research on the Development of Project Cost Informatization in the Era of Big Data. Journal on Big Data, 2(2), 63. https://doi.org/10.32604/ibd.2020.011214

Lytvyn, A., Lytvyn, V., Rudenko, L., Pelekh, Y., Didenko, O., Muszkieta, R., \& Żukow, W. (2020). Informatization of technical vocational schools: Theoretical foundations and practical approaches. Education and Information Technologies, 25(1), 583-609. https://doi.org/10.1007/s10639-019-09966-4

Melnyk, N., Dyvak, M., Melnyk, B., Stakhiv, P., Dyyak, I., \& Mykhailyshyn, R. (2020). Modeling Seller Behavior in the Ukrainian Computer Market. In 2020 10th International Conference on Advanced Computer $\begin{array}{llll}\text { Information } & \text { Technologies }\end{array}$ https://doi.org/10.1109/ACIT49673.2020.9208975

Microsoft Excel. https://www.office.com/launch/excel?ui=uk-UA\&rs=UA\&auth=1

Mwalupaso, G. E., Wang, S., Eshetie, A. M., \& Tian, X. (2020). Ameliorating Food and Nutrition Security in Farm Households: Does Informatization Matter?. Sustainability, 12(2), 522. https://doi.org/10.3390/su12020522

National Commission for the State Regulation of Communications and Informatization. https://nkrzi.gov.ua

Network Readiness Index 2019. https://networkreadinessindex.org/2019/wp-content/uploads/2020/03/ The-Network-Readiness-Index-2019-New-version-March-2020-2.pdf

Network Readiness Index 2020. https://networkreadinessindex.org/wp-content/uploads/2020/11/ NRI2020-V8_28-11-2020.pdf

Official Exchange Rates. https://bank.gov.ua/ua/markets/exchangerates?date $=08.03 .2021 \&$ period=daily

Ordenov, S., Polishchuk, O., Skyba, I., \& Shorina, T. (2020). Clarification of problems in modern society in the processes of informatization and globalization. In E3S Web of Conferences (Vol. 164, p. 11037). EDP Sciences. https://doi.org/10.1051/e3sconf/202016411037

Shevchuk, O., Zui, V., Maryniv, I., Davydenko, S., \& Mokhonchuk, S. (2021). Human Right to Internet Access in Healthcare in the "Right to Health Concept": Legal Issues. European Journal of Sustainable Development, 10(2), 286-286. https://doi.org/10.14207/ejsd.2021.v10n2p286

Statistical Yearbook of Ukraine 2017. http://www.ukrstat.gov.ua/druk/publicat/ kat u/2018/zb/11 $\angle$ zb seu2017 u.pdf 
Statistical Yearbook of Ukraine 2019. http://www.ukrstat.gov.ua/druk/publicat/ kat u/2020/zb/11 $\angle z b \_$yearbook 2019.pdf

Sustainable development goals. https://www.undp.org/content/undp/en/home/sustainable-developmentgoals/resources.html

Volume of services sold by service rendering enterprises to different users by type of economic activity I quater 2019 - IV quarter 2020. http://www.ukrstat.gov.ua

Yao, F., Ji, Y., Li, H. X., Liu, G., Tong, W., Liu, Y., \& Wang, X. (2020). Evaluation of informatization performance of construction industrialization EPC enterprises in China. Advances in Civil Engineering. https://doi.org/10.1155/2020/1314586

Zadorozhnyi, Z. M., \& Muravskyi, V. (2020). Analysis of the Implementation Efficiency of the new Computercommunication Form of Accounting. In 2020 10th International Conference on Advanced Computer Information Technologies (ACIT) (pp. 718-721). IEEE. https://doi.org/10.1109/ACIT49673.2020.9208866

Zhang, H., \& Fang, M. (2020). Research on the integration of heterogeneous information resources in university management informatization based on data mining algorithms. Computational Intelligence. https://doi.org/10.1111/coin.12365

Zhu, J., \& Sun, Y. (2020). Dynamic modeling and chaos control of sustainable integration of informatization and industrialization. Chaos, Solitons \& Fractals, 135, 109745. https://doi.org/10.1016/ j.chaos. 2020.109745 